\title{
A case of communal nesting in the Neotropical snake Sibynomorphus mikanii (Serpentes, Colubridae)
}

\author{
Cristina España Albuquerque $^{1,2}$ and Hebert Ferrarezzi ${ }^{1}$ \\ 1 Laboratório de Herpetologia, Instituto Butantan, 05535-900, São Paulo, SP, Brazil. \\ E-mail: hferrarezzi@butantan.gov.br. \\ 2 Universidade de São Paulo, Faculdade de Medicina Veterinária e Zootecnia, Departamento de Cirurgia, 05508-900 \\ São Paulo, SP, Brazil. E-mail: cris.espana@butantan.gov.br.
}

Keywords: Serpentes, Colubridae, Sibynomorphus mikanii, reproductive biology, communal nesting, egg clutches.

\begin{abstract}
Espinosa and Lobo (1996) defined communal oviposition as "the nonincidental deposition of eggs at a shared nest cavity by two or more conspecifics”. Reports of communal nesting are common among Neartic (Fowler 1966, Brodie et al. 1969, Parker and Brown 1972, Palmer and Braswell 1976, Swain and Smith 1978), Paleartic (Goin and Goin 1971), and Australian (Covacevich and Limpus 1972) snakes, but virtually unknown within Neotropical taxa. The only known cases for South American snakes involve just a few females of Dipsas oreas from the Peruvian Andes (Cadle and Chuna 1995), and Philodryas patagoniensis and Psomophis obtusus from Uruguay (Vaz-Ferreira et al. 1970), all with regards to cold climate inhabitants. These, however, may represent occasional aggregation rather than true cases of communal nesting.

We currently report a noticeable case of nonincidental communal nesting of another dipsadine colubrid snake, Sibynomorphus
\end{abstract}

Received 11 March 2004.

Accepted 16 June 2004.

Distributed 30 September 2004. mikanii (Schlegel, 1837).

Sibynomorphus mikanii, an inhabitant of mesophytic forests mainly within the Cerrado of the Upper Paraná, Upper São Francisco and Upper Tocantins basins (Franco 1994), is a very common snake in urbanized areas of southeastern Brazil (O. A. V. Marques pers. comm.). Sibynomorphus mikanii has a seasonal reproductive cycle, with oviposition occurring from November to January, and recruitment after 12 to 13 weeks (Laporta-Ferreira et al. 1986, Franco 1994, Marques 1998). The clutch size varies from three to 10 eggs (mean $5.9 \pm 1.7$ ) (Oliveira 2001).

A total of 66 eggs were found in Jundiaí

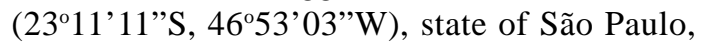
southesatern Brazil, during a land cleaning in an urban area. Eggs were in a humid ravine comprised of soil and overlapped pieces of concrete wall (pulled down) forming a hole of approximately $15 \mathrm{~cm}$ height, $35 \mathrm{~cm}$ width and $60 \mathrm{~cm}$ depth, covered by grass (Figure 1). All eggs were found together, in contact but not adhered one to another. They were donated to the Instituto Butantan on January 7, 2003, some days after collection. By this time, ten eggs had 
Table 1 - Size and weight measurements of egg clutches, embryos and newborn (as grouped by sharing the same developmental stage) in a communal nest of Sibynomorphus mikanii.

\begin{tabular}{ccccccccccccc}
\hline $\begin{array}{c}\text { Collection } \\
\text { number }\end{array}$ & N & \multicolumn{2}{c}{ egg length $(\mathrm{mm})$} & \multicolumn{2}{c}{ egg width $(\mathrm{mm})$} & \multicolumn{2}{c}{ egg mass $(\mathrm{g})$} & \multicolumn{2}{c}{ embryo length (mm) } & embryo mass (g) \\
\hline & & & range & mean & range & mean & range & mean & range & mean & range & mean \\
\hline 70000 & 7 & $27.24-32.27$ & 29.35 & $13.41-15.83$ & 14.74 & $3.07-4.64$ & 3.75 & $101.00-119.00$ & 113.25 & $0.56-0.90$ & 0.84 \\
70001 & 10 & $25.49-27.79$ & 26.46 & $13.62-16.87$ & 15.88 & $3.11-4.25$ & 3.91 & $120.00-145.00$ & 132.28 & $0.70-1.36$ & 1.16 \\
70002 & 4 & $26.25-32.08$ & 30.31 & $14.79-16.01$ & 15.63 & $4.00-4.86$ & 4.43 & $150.00-158.00$ & 153.00 & $1.58-1.87$ & 1.65 \\
70003 & 7 & $23.08-28.63$ & 25.65 & $13.34-15.90$ & 14.09 & $2.62-4.00$ & 3.14 & $67.00-101.00$ & 78.83 & $0.30-0.51$ & 0.41 \\
70004 & 5 & $27.00-30.06$ & 27.51 & $16.11-17.93$ & 16.50 & $4.10-5.02$ & 4.36 & $153.00-166.00$ & 158.89 & $1.39-2.13$ & 1.81 \\
70005 & 9 & - & - & - & - & - & - & $149.00-167.00$ & 159.20 & $1.61-2.02$ & 1.84 \\
70006 & 5 & $21.51-29.08$ & 25.51 & $12.69-14.97$ & 13.69 & $2.64-3.28$ & 2.99 & - & - & $0.12-0.32$ & 0.18 \\
not & 10 & newborns & - & - & - & - & - & - & - & - & - & - \\
70007 & 7 & $21.72-30.15$ & 24.77 & $12.71-14.7$ & 13.9 & $2.32-3.72$ & 2.98 & - & - & $0.46-0.57$ & 0.49 \\
\hline
\end{tabular}

hatched. Eggs, embryos, and hatchlings were measured and weighed. Each removed embryo was observed with regards to morphology in order to determine its developmental stages (Girons 1923, Hubert 1923, Zher 1962), as an aid to infer the minimum number of different females contributing to the communal nesting. The number of clearly different developmental stages was compared to the variation and mean number of eggs laid per female, as determined from a previous study (Oliveira 2001) was compared with the number of females contributing to the communal nesting. Embryos and newborns were deposited in the herpetological collection of Instituto Butantan (IB 70000-70007).

Distinct developmental stages were represented in the communal clutch, based on increasing size and structural development of morphological features. The last parameter includes body scales and head shields construction, the heart and brain visible or not, trunk bending, maxillary process, eye pigmentation, cloacal mound, hemipenis everted or not, cervical flexure, pigmentation visible or not, and development of the pigmentation pattern. Our class A represents the most premature developmental stage found, and so on, following a progressive order in which class $\mathrm{H}$ represents the last developmental stage (i.e., the newborns).

The analysis of the embryos indicated eight visually distinct developmental stages (A-H) demonstrating that at least eight different females contributed to the communal clutch (Table 1). However, S. mikanii lays a mean of 5.9 eggs at a time (Oliveira 2001). Based on our observation that sets of eggs at specific developmental stages exceeded the number of eggs found in single clutches; it is likely that egg classes in developmental stages $\mathrm{B}, \mathrm{F}$, and $\mathrm{H}$ originated from spawning by two or more different females nearly the same time, while the other egg classes (A, C, D, E, and G) must have been laid at different times, added to the same nest successively. Thus we can deduce that the total of 66 eggs could have resulted from eight to 11 different oviposition events.

Nest site selection in reptiles (excluding birds) has been studied for a few species (Heatwole 1977). Descriptions of nest sites of snakes are cursory or based on small sampled or random observations. Snakes usually oviposit in suitable microenvironments beneath logs, under leaf litter, debris (Wright and Wright 1957) or within ant nests (Vaz-Ferreira et al. 1970). 
All reports of Sibynomorphus mikanii laying eggs have been based on captivity data (Laporta-Ferreira et al. 1986, Oliveira 2001), and natural nesting has not been observed for the species. The 66 eggs that we found were in a cavity covered by grass (Figure 1). This site was presumably chosen because it provided protection against impact, predators, and inclement weather. Also, suitable sites for egg laying in proximity of an urban area may be in short supply, and this was the only site which was flat and protected by a slope. Egg aggregations offer potential advantages such as protection (Jackson 1989), predator satiation (Jackson 1989, Eckrich and Owens 1995), and thermoregulation (Booth and Astill 2001). However separate nest sites, each with optimum conditions, would presumably maximize survival of offspring (Swain and Smith 1978). Previous personal observations by one of us (HF) in the field involving several individuals resting close together suggest at least aggregation, if not social affinity, and communal nesting may be an expression of a tendency to aggregate.

Two factors thus appear to have collaborated to the production of a communal nest: environmental limitation and tendency to aggregate. However further observations on natural clutches of this species are necessary to explain the significance of these and other factors causing communal nesting behavior of $S$. mikanii. Aggregation occur in another malacophagous colubrid snake (Tomodon dorsatus) and may be related to available food, abundance of slugs (Bizerra 1998).

The taxonomic distribution of the known cases of snake communal nesting includes the colubrid subfamilies Colubrinae (tribe Colubrini), Natricinae (tribe Natricini), Dipsadinae (tribe Dipsadini, subtribe Dipsadina), and the North American xenodontines (some independent lineages), as well as the hydropheine elapid Demansia (Fowler 1966, Brodie et al. 1969, Parker and Brown 1972, Palmer and Braswell 1976, Swain

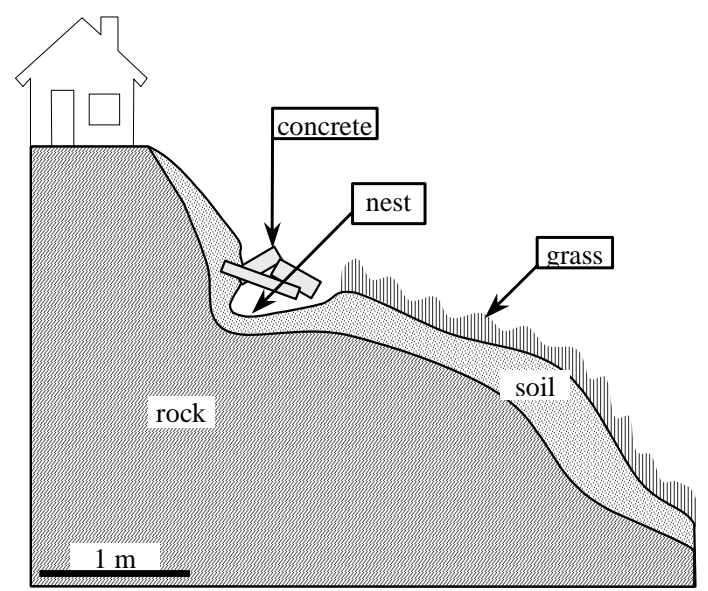

Figure 1 - Diagrammatic vertical section of the terrain surrounding the reported Sibynomorphus mikanii communal nest.

and Smith 1978, Goin and Goin 1971, Covacevich and Limpus 1972, Cadle and Chuna 1995), following the classifications of Ferrarezzi (1994a,b) and Zaher (1999). Most cases refer to species inhabiting cold climates (i.e. the Holartic region). Within Neotropical xenodontines, and considering the present report, all the known cases are restricted to the subfamily Dipsadinae, especially to the gooeaters lineage (tribe Dipsadini). Only after the gathering of further information for Neotropical snakes, we could decide if this occurred randomly or if it may represent a phylogenetic trend or pattern of such colubrid clade.

\section{Acknowledgements}

We thank O. A. V. Marques, H. Greene, L. P. Prado, and M. A. Gioso for the critical review of the manuscript and J. L. Oliveira for have kindly provided her unpublished information, to the staff of the Departamento de Zoonoses da Prefeitura Municipal de Jundiaí for the material donation, to T. M. Castellar and F. E. Barbo for helping collecting data, and to FAPESP for financial support. 


\section{References}

Bizerra, A. F. 1998. História natural de Tomodon dorsatus (Serpentes, Colubridae). Unpublished M.Sc. Dissertation. Universidade de São Paulo, Brazil.

Booth, D. T. and K. Astill. 2001. Temperature variation within and between nests of the green sea turtle Chelonia mydas (Chelonia: Cheloniidae) on Heron Island, Great Barrier Reef. Australian Journal of Zoology 49: 71-84.

Brodie, E. D., Jr., R. A. Nussbaum and R. M. Storm. 1969. An egg-laying aggregation of five species of Oregon reptiles. Herpetologica 25: 223-227.

Cadle, J. E. and P. M. Chuna. 1995. A new lizard of the genus Macropholidus (Teiidae) from a relictual humid forest of northwestern Peru, and notes on Macropholidus ruthveni Noble. Breviora 501: 1-39.

Cook, F. R. 1964. Communal egg laying in the smooth green snake. Herpetologica 20: 206.

Covacevich, J. and C. Limpus. 1972. Observation on community egg-laying by the Yellow-faced whip snake, Demansia psammophis (Schlegel) 1837 (Squamata, Elapidae). Herpetologica 28: 208-210.

Eckrich, C. E. and D. W. Owens. 1995. Solitary versus arribada nesting in the olive ridley sea turtle (Lepidochelis olivacea): a test of the predator satiation hypothesis. Herpetologica 51: 349-354.

Espinoza, R. E. and F. Lobo. 1996. Possible communal nesting in two species of Liolaemus lizard (Iguania: Tropiduridae) from northern Argentina. Herpetological Natural History 4: 65-68.

Ferrarezzi, H. 1994a. Uma sinopse dos gêneros e classificação das serpentes (Squamata). I. Scolecophidia e Alethinophidia não colubrídeos. Pp. 69-80 in L. B. Nascimento, A. T. Bernardes and G. A. Cotta (eds.), Herpetologia no Brasil I. Belo Horizonte. PUC-MG/ Fundação Biodiversitas/Fundação Ezequiel Dias.

Ferrarezzi, H. 1994b. Uma sinopse dos gêneros e classificação das serpentes (Squamata). II. Família Colubridae. Pp. 81-91 in L. B. Nascimento, A. T. Bernardes and G. A. Cotta (eds.), Herpetologia no Brasil 1. Belo Horizonte. PUC-MG/ Fundação Biodiversitas/Fundação Ezequiel Dias.

Fowler, J. A. 1966. A communal nesting site for the smooth green snake in Michigan. Herpetologica 22: 231.

Franco, F. L. 1994. O gênero Sibynomorphus Fitzinger, 1843 no Brasil (Colubridae: Xenodontinae, Dipsadini). Unpublished M.Sc. Dissertation. Pontifícia Universidade Católica do Rio Grande do Sul, Brazil.

Girons, H. S. 1923. Comparative data on Lepidosaurian reproduction and some time tables. Pp. 35-58 in C. Gans (ed.), Biology of the Reptilia. Vol. 15. New York. Alan R. Liss Inc.
Goin, C. J. and O. B. Goin. 1971. Introduction to Herpetology. 2nd ed. San Francisco. W. H. Freeman and Co.

Heatwole, H. 1977. Habitat selection in reptiles. Pp. 137155 in C. Gans and D. W. Tinkle (Eds.), Biology of the Reptilia. Vol. 7. New York. Academic Press.

Hubert, J. 1923. Embryology of the Squamata. Pp 1-34 in C. Gans (ed.), Biology of the Reptilia. Vol. 15. New York. Alan R. Liss, Inc.

Jackson, D. 1989. Turtles use of alligator nests. Pp. 145in C. A. Ross (ed.), Crocodiles and Alligators. London. Merchurst Press.

Laporta-Ferreira, I. L., M. G. Salomão and P. Sawaya. 1986. Biologia de Sibynomorphus (ColubridaeDipsadinae): reproducão e hábitos alimentares. Revista Brasileira de Biologia 46: 793-799.

Marques, O. A. V. 1998. Composição faunística, história natural e ecologia de serpentes da Mata Atlântica, na região da Estação Ecológica Juréia-Itatins, São Paulo, SP. Unpublished Ph.D. Thesis. Universidade de São Paulo, Brazil.

Oliveira, J. L. 2001. Ecologia de três espécies de dormideira, Sibynomorphus (Serpentes: Colubridae). Unpublished M.Sc. Dissertation. Universidade de São Paulo, Brazil.

Palmer, W. M. and A. L. Braswell. 1976. Communal egg laying and hatchlings of the rough green snake, Opheodrys aestivus (Linnaeus) (Reptilia, Serpentes, Colubridae). Journal of Herpetology 10: 257-259.

Parker, W. S. and W. S. Brown. 1972. Telemetric study of movements and oviposition of two female Masticophis t. taeniatus. Copeia 1972: 892-895.

Rand, A. S. 1967. Communal egg laying in anoline lizard. Herpetologica 23: 227-230.

Swain, T. A. and H. M. Smith. 1978. Communal nesting in Coluber constrictor in Colorado. Herpetologica 34: 175-177.

Vaz-Ferreira, R., L. Covelo de Zolessi and F. Achával. 1970. Oviposicion y desarrollo de ofídios y lacertílios em hormigueros de Acromyrmex. Physis XXIX 79: 431-459.

Wright, A. H. and A. A. Wright. 1957. Handbook of Snakes of the United States and Canada. Ithaca. Cornell University Press.

Zaher, H. 1999. Hemipenial morphology of the South America xenodontine snakes, with a proposal for a monophyletic Xenodontinae and a reappraisal of colubroid hemipenis. Bulletin of the American Museum of Natural History 214: 1-168.

Zehr, D. R. 1962. Stages in the normal development of the common garter snake, Thamnophis sirtalis sirtalis. Copeia 1962: 322-329. 